\title{
A CIDADE, A MEMÓRIA E A FESTA: O CONGADO E OS SENTIDOS DE NEGRITUDE NA PAISAGEM PATRIMONIAL DE OURO PRETO-MG
}

The city, the memory and the party: the Congado and the senses of blackness in the heritage landscape of Ouro Preto-MG

\section{Patrício Pereira Alves de Sousa}

Geógrafo, Professor e Pesquisador do Programa de Pós-Graduação em Relações Étnico-Raciais do Centro Federal de Educação Tecnológica Celso Suckow da Fonseca (PPRER-CEFET/RJ), Brasil

patricio.sousa@cefet-ri.br

\section{Resumo}

O artigo apresenta os resultados de uma pesquisa que tratou das disputas em torno dos significados de negritude presentes nas paisagens patrimoniais de Ouro Preto-MG entre as instituições de conservação da memória e os sujeitos que atualmente realizam naquela cidade uma festa de coroação de reis negros. As diferentes versões memoriais que concorrem pela representação pública das identidades negras são debatidas no texto a partir de dois eixos analíticos principais: os lugares e os itinerários simbólicos. Para a investigação foi adotada uma perspectiva interpretativa baseada na análise de documentos, obras artísticas, construções arquitetônicas e percursos turísticos, conjugados ao trabalho de campo de observância das festas e à condução de entrevistas. A imersão na paisagem ouro-pretana e a interação com os congadeiros possibilitou indicar o modo como os rituais do Congado produzem itinerários simbólicos insurgentes consoantes à ressignificação das imagens hegemônicas de negritude veiculadas pelos órgãos oficiais de conservação da memória.

Palavras-chave: Negritude, Festa, Paisagem, Patrimônio, Congado, Ouro Preto.

\section{Abstract}

The article presents the results of a research that dealt with the disputes over the meanings of blackness present in the heritage landscapes of Ouro Preto-MG between the institutions of memory conservation and the subjects that currently hold a celebration of black kings in that city. The different memory versions that compete for the public representation of black identities are discussed in the text from two main analytical axes: the places and the symbolic itineraries. To the investigation, an interpretative perspective was adopted based on the analysis of documents, artistic works, architectural constructions and tourist routes, conjugated with the fieldwork of observance of the parties and the conduction of interviews. The immersion in Ouro Preto landscape and the interaction with congadeiros made possible to indicate the way in which the Congado rituals produce insurgent symbolic itineraries according to the re-signification of the hegemonic images of blackness disclosed by the official organs of memory maintenance.

Keywords: Blackness, Party, Landscape, Heritage, Congado, Ouro Preto. 


\section{INTRODUÇÃO}

As festividades são uma característica marcante da cultura brasileira. Conforme destaca Amaral (1998), estando presentes no país desde antes da colonização e tendo sido diversificadas a partir da chegada de africanos e europeus, as festas atuaram na elaboração das identidades forjadas pelo violento encontro intercultural que originou o Brasil. Elas participaram da formulação de linguagens, modos de ação e cosmologias, tendo desempenhado ainda importante papel na mediação entre povos ao permitir a comunicação entre os diferentes grupos étnico-raciais. Em muitos casos, as festas viabilizaram a afirmação do poder dos grupos dominantes e o estabelecimento de hierarquias sociais. Em outros, elas foram as maiores estratégias de resistência contra a repressão do poder político e religioso, garantindo a manutenção e a reinvenção no tempo e no espaço dos grupos sociais subalternizados. Nos termos de DaMatta (1980, p. 14-15) é possível afirmar, portanto, que as festas ajudaram a fazer do brasil, o Brasil. Elas forneceram as coordenadas para "os caminhos que tornaram a sociedade brasileira diferente e única $[\ldots] "$.

Embora o campo de estudos das festas seja relativamente recente nas ciências sociais brasileiras, algumas disciplinas já têm criado suas próprias tradições. Antropologia, história e sociologia são exemplos de áreas em que a festa já é tomada como objeto e conceito relevante. No caso da geografia, o reconhecimento da temática tem sido mais tímido. Conforme avaliação de especialistas (DEUS et. al. 2016; SOUSA, 2016; MAIA, 2002), as festas ainda se constituem em campo restrito na Geografia Brasileira, seja no quantitativo de pesquisas produzidas ou no impacto das reflexões resultantes dessas pesquisas na formulação de conceitos e teorizações na disciplina.

Partindo deste entendimento de que as festas podem mais ativamente contribuir para a compreensão da espacialidade das sociedades, neste artigo comunico as questões centrais e os principais resultados de uma pesquisa de tese (SOUSA, 2018) em que analisei o modo como determinados sujeitos festejantes participam das disputas pelos sentidos de negritude comunicados a partir da paisagem ${ }^{1}$ de uma cidade

\footnotetext{
1 Neste texto considero a paisagem como um campo de disputas pela afirmação do poder simbólico, compreendendo-a como uma elaboração realizada sempre em relação a um campo discursivo e estando envolvida em tensões em torno do poder (DANIELS e COSGROVE, 1993). A paisagem se constitui, nessa compreensão, como um texto que congrega um conjunto de códigos e símbolos inscritos pelos sujeitos que, em interação, produzem o espaço (DUNCAN, 1990). Dessa maneira, embora a paisagem possua uma dimensão material, o que a define é um sistema interconectado de códigos que comunicam, reproduzem e contestam símbolos. Na condição de instrumento cultural ela pode ser entendida como um complexo de significados materiais, verbais e visuais que define a maneira como concebemos o mundo, participando tanto dos processos de afirmação quanto de contestação do poder (COSGROVE e DANIELS, 1989).
} 
patrimonial. De modo mais específico, o estudo investigou as tensões existentes entre as representações hegemônicas de raça e etnicidade conformadas pelos espaços de memória em Ouro Preto-MG e as versões de negritude construídas por grupos de Congado que desde o período colonial realizam festas de coroação de reis negros naquela cidade.

Metodologicamente, a pesquisa foi realizada a partir de uma abordagem interpretativa que permitiu tratar, a partir da aproximação com os trabalhos de Geertz (1989) e Duncan (1990), as festas de Congado e a paisagem patrimonial de Ouro Preto como manuscritos repletos de inscrições e como uma sobreposição de textos escritos a muitas mãos. No esforço de leitura desses "manuscritos", me aproximei de materiais muito diversos. Documentos históricos e dossiês de tombamento foram apreciados, guias de viagem decodificados, sites institucionais visitados, romances e filmes históricos lidos e assistidos, museus percorridos, itinerários turísticos frequentados e festas experienciadas. Entrevistei ainda autoridades rituais, burocráticas e acadêmicas. Li e reli diversos estudos já realizados sobre a cidade. Assim, ao longo da pesquisa, imergi numa paisagem, me tornando um observador participante de seus processos, ritmos e conteúdos, me deixando levar por seus movimentos cotidianos e seus eventos excepcionais. Em porte de um vasto universo de informações, os organizei de modo a compartilhar uma leitura que, longe de se pretender completa e definitiva, permitiu uma interpretação guiada por um modo de estar em Ouro Preto e nas festas de Congado em que pude ver, sentir e pensar sobre as densidades simbólicas que fazem daquele um lugar destacado para tantas pessoas e coletividades.

No recorte estabelecido para este artigo, a problematização que apresento está concentrada na análise das relações existentes entre os fixos e os fluxos que em conjunto constituem o espaço festivo, indagando as relações que estabelecem entre si os lugares e os itinerários simbólicos. Assim, nas seções que se seguem no texto, discuto como as festas de Congado se constituem como itinerários simbólicos que afirmam, contestam ou atualizam as imagens de negritude no lugar simbólico em que se constitui Ouro Preto.

\section{POR UMA GEOGRAFIA DAS FORMAS SIMBÓLICAS ESPACIAIS}

Corrêa (2012), ao tratar da geografia das formas simbólicas espaciais, indica que esse campo analítico se ocupa dos fixos e fluxos que dotam o espaço geográfico de significados. Nesta reflexão me aproximo da proposta apresentada pelo autor de 
compreender as formas simbólicas espaciais a partir de duas noções fundamentais, a de lugares simbólicos e a de itinerários simbólicos.

Por lugares simbólicos, Corrêa (2012) define os espaços que ganham singularidade por serem impregnados de significados políticos, religiosos, étnicos ou históricos. Esses lugares são considerados de especial valor para um grupo ou nação, o que gera interesses na sua preservação ou faz com que determinadas coletividades reivindiquem a sua apropriação ou controle. Os templos, cemitérios e memoriais são exemplos emblemáticos desses lugares.

Ao tratar da dinâmica que transforma os espaços indistintos em lugares de destacada significação, Mandoki (1998) sugere que alguns dos sítios onde se desenvolvem a vivência humana se tornam realçados em função das camadas de experiências, histórias e emoções que neles se acumulam. Conforme indica a autora, desde as primeiras formas de organização social cada coletividade tem preenchido seus espaços com conteúdos simbólicos que os tornam lugares particulares. À ampla dimensão do espaço foram sendo conferidos valores diferenciados e hierarquizações, fazendo com que alguns desses lugares fossem singularizados e se tornassem de destacado interesse por serem considerados os exatos sítios onde eventos relevantes ocorreram.

Uma característica especial desses lugares simbólicos é que eles se tornam uma espécie de campo gravitacional. Por serem simbolicamente densos, eles passam a ter um poder diferenciado de atração de novos eventos e camadas de sentidos. Assim, além de serem importantes por aquilo que em um primeiro momento os tornou sítios de histórias e valores emocionais específicos, esses lugares se tornam atrativos de mais episódios que tendem a enriquecê-lo com novas camadas de significação. Esses lugares são, portanto, não apenas espaços e não são eles o oposto do tempo: lugares simbólicos são os espaços tecidos pelo tempo (MANDOKI, 1998).

Os itinerários simbólicos, por sua vez, se relacionam com os tipos especiais de deslocamento de objetos e pessoas para que a produção, circulação, comunicação e consumo de significados se estabeleça. Como propõe Corrêa (2012), procissões, marchas e desfiles são eventos que configuram esses itinerários. Nesta reflexão, os itinerários de relevância são aqueles configurados pelas festas e, mais especificamente, pelos rituais produzidos pelas chamadas "festas de santo".

Sendo a festa, como define Durkheim (1989), um evento coletivo e uma ocasião em que o ser humano se exterioriza a partir de atos de efervescência, ela é também um 
evento necessariamente espacial. Assim, como propõe Duvignaud (1983), a festa necessita se apropriar dos espaços para se estabelecer, uma vez que é através de sua extensão que os seres humanos podem se colocar na situação de encontro e comunicação para celebrar algo e expor seus desejos. DaMatta (1980) sugere mesmo que o fato mais marcante das festas se constitui na retirada dos objetos dos seus lugares e da circulação das pessoas por determinados espaços, vide a força das peregrinações. $A$ festa é, portanto, como pondera Perez (2002), uma coisa pública e do domínio da rua. Afinal, tanto o festejar como o ato de sair de casa coincidem em um abandono consciente de uma situação de controle, onde todas as coisas são domináveis, rumo a circunstâncias em que as coisas estão fora de seus lugares e os imprevistos são iminentes (DAMATTA, 1980).

As diferentes festas possuem, no entanto, modos distintos de lidar com os deslocamentos, sejam eles os espaciais ou os sociais. Numa festa de santo ou no carnaval, por exemplo, os mecanismos que orientam as ações têm características próprias. Considerando as festas de santo, tomadas como mais regradas e comedidas que os carnavais, podemos conceber que seus itinerários simbólicos tanto podem ser um instrumento para afirmação quanto para contestação de hierarquias. Ao tratar do assunto, Sanchis (1983) chama atenção para como o problema do espaço é uma questão fundamental nas festas de santo. Por elas geralmente possuírem o objetivo de projetar o sagrado para fora dos santuários, elas colocam em rivalidade e enfrentamento pelo menos dois polos: o clero e o povo. Enquanto os agentes da igreja querem restringir o sagrado apenas ao seu entorno próximo para manter a ordem e evitar os excessos, o povo vê a procissão e o cortejo como propriedades suas, em que ele pode expandir como em nenhum outro momento - a extensão do sagrado. Assim, como festa do povo, as festas de santo são, apesar de sua aura conservadora, uma forma de rompimento de hierarquias. Colocando o santo na rua, ela o torna coisa pública, estendendo tanto quanto possível o sagrado na vida comum e fazendo dele um instrumento de comunicação e regozijo. Isso demarca as procissões e cortejos como itinerários simbólicos, uma vez que nas festas de santo o sagrado é estabelecido justamente quando seus signos se deslocam pelo espaço (ROSENDAHL, 2002).

Ainda sobre o campo da geografia das formas simbólicas, Corrêa (2012) aponta que as noções de lugares simbólicos e itinerários simbólicos polarizaram a quase totalidade dos trabalhos desenvolvidos pela Geografia Cultural pós-1970. Não obstante a qualidade desses trabalhos, seus focos analíticos estiveram baseados na apreciação e 
aprofundamento de uma ou outra dessas noções separadamente. Poucas foram as investigações que explicitamente se ocuparam da relação de complementaridade ou antagonismo entre os lugares e os itinerários simbólicos. Em função do exposto, esta reflexão problematiza a maneira como se relacionam essas duas noções, ao colocar com questões centrais as seguintes perguntas: I) Que relações estabelecem entre si os itinerários simbólicos e os lugares simbólicos?; II) Qual o papel dos lugares simbólicos na configuração da forma e na constituição do conteúdo dos itinerários simbólicos?; III) Os itinerários simbólicos podem alterar o conteúdo de lugares simbólicos quando a eles se associam?; IV) De que maneira os itinerários simbólicos afirmam, contestam ou atualizam os lugares simbólicos?

A fim de balizar as indagações acima apresentadas, realizo uma análise pautada na consideração da relação entre um lugar e um itinerário simbólicos específicos. Assim, a reflexão foi encaminhada em duas frentes de trabalho: uma primeira, que interpretou os conjuntos monumentais que formam a paisagem patrimonial de Ouro Preto como lugares simbólicos; e outra, que analisa os festejos de coroação de reis negros que ocorrem naquele local como itinerários simbólicos. As perguntas feitas diretamente ao caso de estudo ficam, então, assim configuradas: i) Que relações estabelecem entre si os festejos de coração de reis negros e o conjunto patrimonial ouro-pretano? ii) Qual o papel de Ouro Preto na configuração da forma e na constituição do conteúdo das festas de Congado? iii) As festas do Congado podem alterar o conteúdo simbólico do conjunto monumental de Ouro Preto quando a ele se associam? iv) De que maneira os festejos de coroação de reis negros afirmam, contestam ou atualizam a paisagem patrimonial ouro-pretana?

Considerando que o estudo se ocupa das relações entre os lugares e os itinerários simbólicos e que a análise examina as disputas pelos significados identitários comunicados pela paisagem patrimonial de Ouro Preto, podemos considerar que o que se encontra em disputa são os imaginários, representações e emocionalidades construídos a partir dos conjuntos monumentais. Para início de reflexão devemos, então, melhor compreender como Ouro Preto se constituiu como um lugar simbólico e como as narrativas de negritude foram elaboradas a partir de suas paisagens.

\section{OURO PRETO: UM LUGAR SIMBÓLICO}

A cidade de Ouro Preto, em Minas Gerais, é amplamente conhecida no país em função de sua rica arte e arquitetura barroca e colonial. Sua posição de precursora nas políticas patrimoniais no Brasil, que a levaram a ser a primera reconhecida como 
patrimônio mundial pela Organização das Nações Unidas para Educação, Ciência e Cultura (UNESCO), em 1980, e a primeira a ser declarada monumento nacional pelo Instituto do Patrimônio Histórico e Artístico Nacional (IPHAN), em 1933, fazem com que ela contemporaneamente ainda figure como um importante cenário educativo para a construção da identidade nacional. Tendo suas imagens reproduzidas em cartões postais, livros didáticos, obras artísticas, sites e revistas de viagem, a cidade atrai a cada ano milhares de turistas, peregrinos, estudantes, professores, intelectuais e artistas que até ela se dirigem para o contato com uma paisagem que informa, sensibiliza e permite a experiência sobre espaços e temporalidades que povoam seus imaginários ${ }^{2}$.

As razões para o recebimento de um contingente elevado de pessoas e a circulação destacada de imagens da cidade são diversas. Seja em função da arte barroca ou dos investimentos feitos por arquitetos modernistas na cidade, seja pelas referências católicas ou de outras matrizes festivo-religiosas, fato é que Ouro Preto, embora possa ser tomada como um ponto no mapa dividindo espaço com os outros mais de cinco mil municípios do Brasil, possui uma distinção em relação às demais cidades por congregar uma série de elementos que foram responsáveis pela construção do sentimento de nacionalidade no país. Por esse motivo, os elementos que fizeram daquela cidade um lugar de densidades simbólicas transcendem sua história local, eles se relacionam com o contexto da formulação do Brasil enquanto uma comunidade nacional. Parafraseando Anderson (2008), ainda que a maioria dos mais de 200 milhões de brasileiros jamais chegue efetivamente a visitar Ouro Preto, a cidade figura no imaginário e nas representações de muitos deles. A confiança na presença constante e simultânea de Ouro Preto entre as mesmas fronteiras territoriais e simbólicas do que outra cidade em que um brasileiro vive, o ajuda a compor parte da imagem que ele tem de si, auxiliando também na significação que ele confere a elementos como seu idioma, suas práticas corporais e seus imaginários geopolíticos e geoculturais.

A posição de destaque de Ouro Preto e sua constituição como um "teatro da memória" através do qual uma retórica oficial da nação pode ser elaborada e divulgada não foi, no entanto, inocente e sua produção não foi acidental (GONÇALVES, 1988). Essa construção foi configurada a partir de imagens que buscaram corresponder a expectativas internas e externas à cidade. As narrativas ficcionais de artistas e intelectuais, os conceitos e critérios de arquitetos e técnicos do patrimônio e a ação de políticos e figuras

${ }^{2}$ Conforme dados a mim fornecidos pela Secretaria Municipal de Turismo, Ouro Preto recebe anualmente cerca de 300 mil turistas, um número quatro vezes maior que o de sua população residente. 
públicas, em conjunto, permitiram a cidade ser confirmada como um modelo a ser seguido e reproduzido por outros sítios patrimoniais que funcionariam como símbolos de um Brasil moderno, civilizado e portador de uma identidade e território conhecidos e comportilhados (CHUVA, 2003; MOTTA, 1987).

Examinando registros escritos em relatos de viagens, textos jornalísticos, pareceres técnicos e artigos em periódicos, Aguiar $(2013 ; 2006)$ identificou, para diferentes contextos históricos, representações hegemônicas sobre a cidade. A partir de sua análise, a autora propõe que três principais imagens sobre Ouro Preto, emersas em sequencialidade, foram construídas, sedimentadas e divulgadas ao longo do tempo: as de cidade morta, cidade monumento e cidade turística.

Resgatando as narrativas produzidas em torno da história de Minas Gerais e de Ouro Preto desde o início do século XVIII, Aguiar (2006) destaca que as principais interpretações realizadas sobre aquela cidade tomam como marco inicial as descobertas auríferas que no final do século XVII levaram ao deslocamento um significativo contingente de pessoas para as terras dos sertões que mais tarde se tornaram as Minas Gerais. Relacionada às bandeiras organizadas por paulistas em busca do ouro, a fixação dessas populações veio a dar origem, no início do século XVIII, às primeiras vilas que um século mais tarde se transformaram na Imperial Cidade de Ouro Preto ${ }^{3}$.

Prosseguindo no exame da bibliografia sobre a formação histórica de Ouro Preto, Aguiar (2013) identificou uma importante transformação na maneira como a cidade passou a ser descrita a partir da passagem entre os séculos XVIII e XIX. Contrastando com as imagens de apogeu da primeira metade do século XVIII, diferentes narrativas sobre Ouro Preto repetiram a interpretação sobre a decadência por ela sofrida ao longo do século XIX. Utilizada como fator explicativo para o declínio econômico da cidade, a radical diminuição do ouro disponível para extração teria acarretado outro evento que tornou ainda mais intensa sua decadência: a transferência da capital do estado de Minas Gerais de Ouro Preto para Belo Horizonte no ano de 1897. Esses fatos em conjunto teriam tornado Ouro Preto, a partir de então, uma cidade morta.

Essa percepção de Ouro Preto como decadente e em ruínas, propagandeada por diversos viajantes e políticos que a percorreram no Oitocentos, começou a se modificar a

\footnotetext{
${ }^{3}$ No ano de 1711 , a partir da junção de diferentes arraiais que aglutinados receberam a denominação de Vila Rica, o espaço urbano que hoje constitui a cidade de Ouro Preto foi elevado à categoria de vila. Anos mais tarde, com a separação das capitanias de Minas e São Paulo, em 1720, Vila Rica foi escolhida como a sede da nova capitania. Em 1823, após a Independência do Brasil, Ouro Preto tornou-se oficialmente a capital de Minas Gerais ao se tornar a Imperial Cidade de Ouro Preto, permanecendo como a sede do estado até o ano de 1897.
} 
partir de uma nova imagem que passou a ser difundida a partir de mineiros ilustres que possuíam relação com a cidade e que ocupavam posições políticas e burocráticas privilegiadas a nível nacional. Assim, a cidade retratada como morta, passou a ser concebida a partir das primeiras décadas do século XX como um lugar agregador de diversos elementos da cultura brasileira. Artigos de intelectuais, somados a discursos políticos e a trabalhos de artistas das belas artes, literatos e arquitetos, participaram da construção de uma ideia de que Ouro Preto e outras cidades mineiras deveriam ser preservadas por abrigarem em seus conjuntos urbanos obras e construções com valores autênticos e tradicionais responsáveis pela construção da nação. Esse período foi aquele em que Ouro Preto se tornou uma cidade imaginada por todo o país, ganhando notoriedade através das construções discursivas que foram criando um consenso sobre ela se constituir numa cidade monumento, uma verdadeira obra de arte a partir da qual o nacional poderia ser exaltado (AGUIAR, 2013; 2006).

Em decorrência dessa construção de Ouro Preto como cidade monumento, outros discursos além do nacionalista ganharam corpo. Como justificativa para gerar fundos que salvaguardassem seus bens ou que incrementassem sua economia, os projetos de desenvolvimento turístico foram vistos como caminhos interessantes para a cidade. Assim, além de uma imagem como bem patrimonial, a construção de Ouro Preto como um destino para viagem e lazer também mobilizou veículos e discursos que a difundiram e a fizeram ser percebida dessa maneira. $O$ fomento à infraestrutura turística, como a construção de leitos para hospedagem e a melhoria nas vias que ligavam os grandes centros àquele destino, passaram, a partir da segunda metade do século $\mathrm{XX}$, a projetar mais amplamente Ouro Preto para o cenário nacional e internacional. Nesse momento, os jornais e periódicos de grande circulação passaram a fazer com que a cidade frequentasse suas páginas a fim de criar sobre Ouro Preto a imagem de uma cidade turística. Essa divulgação, além de ser sustentada por agências e empresas envolvidas na atividade turística, possuiu ainda como propagandistas intelectuais do campo preservacionista, que viam no turismo a possibilidade de salvaguarda dos bens patrimoniais (AGUIAR, 2013; COSTA e SCARLATO, 2009).

Compreender Ouro Preto como uma cidade que participa da composição de imaginários, representações e memórias envolve, portanto, pensar como ela está implicada na elaboração do Brasil como uma organização política, territorial e cultural. Para que possamos examinar as políticas de contestação ou afirmação da negritude nas paisagens ouro-pretanas pelas festas de Congado é necessário, no entanto, que 
analisemos também como outros processos associados ao discurso nacionalista concorreram para a construção das imagens da cidade. Por este motivo, na seção seguinte apresento reflexões sobre as diferentes camadas envolvidas na formulação de Ouro Preto como um lugar simbólico condensador de diferentes discursos sobre as identidades negras.

\section{OS SUJEITOS NEGROS NA PAISAGEM PATRIMONIAL OURO-PRETANA}

Ao analisar a representação "do negro" nos museus brasileiros, Santos (2005) aponta que a imagem produzida sobre o africano e o afro-brasileiro recorrentemente os relaciona a elementos de tortura gerados pela escravidão, não resgatando aspectos de positividade de suas identidades. A construção institucional dos espaços da memória nacional é efetuada, dessa maneira, através de políticas que formulam determinado imaginário sobre aquele outro que é representado. Assim, os museus são elaborados, conforme Koptcke (2005), a partir do projeto criador de certa narrativa que se quer comunicar, através da escolha de peças, seleção de acervo, regulação do acesso e da definição e normatização do comportamento do público visitante. No caso ouro-pretano, em que os espaços de memória não se constituem em unidades museais isoladas, mas em um conjunto patrimonial que configura uma cidade monumento, cabe considerar a existência da produção de uma narrativa espacial que comunica - através da associação de casarios coloniais, prédios históricos, museus, obeliscos e equipamentos urbanísticos , uma determinada versão de passado.

Em Ouro Preto, como já sinalizado, a elaboração ficcional do discurso nacionalista a partir dos monumentos começou a se estabelecer na passagem entre as décadas de 1920 e 1930, quando, influenciados pelo apelo artístico modernista, os governos local e federal formularam as primeiras políticas de gestão da paisagem patrimonial que atingiram a cidade (GONÇALVES, 1988). A partir daí, uma série de outras políticas de instituições de conservação da memória de âmbito municipal, estadual, nacional e supranacional produziu documentos e realizou reformas arquitetônicas e urbanísticas que normatizaram modelos de identidade para dar significado aos espaços e objetos de memória ouro-pretanos. Nessa narrativa espacial elaborada pelos ideólogos do patrimônio e gestores da paisagem de Ouro Preto, como aponta Lima Filho (2010), o elemento edificado como possuidor de identidades positivas foi o sujeito branco, materializado na figura do Inconfidente, que no imaginário construído figura como sendo aquele que conduziu, a partir da bravura e coragem, o Estado brasileiro à independência 
a partir da Conjuração Mineira. Embora esse sujeito, vez ou outra, também seja representado a partir dos qualificativos de tortura e sofrimento, a estética da dor relacionada ao Inconfidente é exibida na narrativa paisagístico-patrimonial apenas como parte de sua história. A "moral da história" dessa narrativa Inconfidente tem por destino a liberdade, tendo a dor um significado sacrifical. A dor representada no discurso patrimonial direcionado ao afro-brasileiro, por outro lado, sintetiza a imagem de um eterno-presente da escravidão. "É como se a noção de liberdade de Tiradentes e dos Inconfidentes fosse maior ou mais merecida que a outra, ou seja, mais significativa para os brancos do que para os negros" (LIMA FILHO, 2010, p. 209).

De acordo com Lima Filho (2010) há, pois, um esforço das políticas patrimoniais em reduzir as populações afrodescendentes no Brasil a uma condição permanente de grupo subalterno, passivo às imposições coloniais e relegado a um dilaceramento das possibilidades de vida grupal altiva, com vitalidade política e potência criativa. Para o autor, essa situação se torna uma realidade evidente especialmente em Ouro Preto. Haveria uma tendência geral das instituições da memória em construir um discurso ingênuo de vitimização das possibilidades patrimoniais relacionadas à cidadania de populações negras de origem diaspórica. Dessa maneira, a política paisagística oficial relacionada a Ouro Preto ignora a presença africana e afro-brasileira como co-partícipe da historicidade local para além da escravidão, desconsiderando os aspectos de vida social que esses grupos inscreveram nos espaços da cidade, como a arte, a filosofia, a estética e a política.

No desenvolvimento da pesquisa em que se baseia este artigo um dos instrumentos utilizados foi a etnografia dos percursos, metodologia proposta por Abreu (2012) e que me permitiu entrar em contato com o amplo e diversificado acervo dos museus de Ouro Preto. Assim, ao percorrer e interpretar as narrativas de museus de diferentes tipologias, pude identificar como nos espaços de memória da cidade as identidades dos povos negros são reificadas de modo a criar sensações como sofrimento, dor, aversão e repulsa. Os museus analisados foram o Museu da Inconfidência, de caráter histórico; o Museu Casa dos Contos, especializado na memória fiscal e monetária do país; e o Museu de Ciência e Técnica da Escola de Minas de Ouro Preto.

$\mathrm{Na}$ intepretação das narrativas o que foi possível constatar é que a questão étnicoracial se faz presente em duas modalidades. A primeira delas traz em excesso o sujeito negro representado como escravizado em gravuras e estátuas, restringindo seu aparecimento a situações de trabalho forçado e a objetos de tortura, como chicotes, 
armadilhas de captura, palmatórias, algemas, gargalheiras, ferro de marcar e esmagador de testículos. Essas são imagens encontradas principalmente em museus como o da Inconfidência e o da Casa dos Contos, em que as peças e representações da arte e vida coletiva negra são raras. A segunda forma de representação da questão étnico-racial nos museus ouro-pretanos é a que faz o sujeito negro ausente, situação encontrada no Museu de Ciência e Técnica, que, ao trazer uma visão privilegiada da branquitude associada aos eventos de evolução da ciência, sugere, por contraste, ser o negro não produtor de conhecimento, técnica e engenhosidade. Essas duas modalidades representacionais, quando associadas, corroboram para a mitificação do sujeito branco como portador de historicidade, elevação moral e capacidade inventiva e do sujeito negro como destituído de potência política e cultural, não produtor de arte e conhecimento e cristalizado numa permanente posição de subalterno.

A pesquisa também permitiu identificar, no entanto, elementos de positividade associadas aos povos africanos e afrodescendentes em Ouro Preto. É assim que as biografias de sujeitos negros que têm lugar em alguns espaços de memória e que possuem importância para suas cosmologias puderam ser identificadas. Como aquela cidade por muito tempo agregou e ainda agrega um elevado quantitativo de pessoas negras, há, ainda que dispersos e em narrativas menos estruturadas, objetos, materialidades e simbologias possíveis de serem recuperadas para indicar que, para além da dimensão da escravização, os africanos e seus descendentes no Brasil carregavam/carregam uma série de visões de mundo e práticas religiosas, modos de morar e construir, de estabelecer relação com seus corpos e alimentação, de ritualizar suas sociabilidades e de perpetuar as marcas de suas existências no tempo e no espaço. Assim, além de possuir elementos de uma paisagem racializada que reifica as identidades negras, Ouro Preto também porta aspectos que indicam para uma imagem da negritude como a de povos altivos, ativos e portadores de complexos sistemas filosóficos, artísticos e políticos. Trata-se, portanto, de uma paisagem complexa e possuidora de múltiplas camadas, uma vez que sua produção não se formulou a partir da ação de um agente único, mas pelos enfrentamentos e tensões entre diversos grupos étnico-raciais e classes sociais.

Dessa forma, semelhante às etnografias dos percursos que realizei para os museus, pude também percorrer igrejas e capelas que possuem imagens dos santos negros e de devoção negra, como São Benedito, Santo Antônio de Noto, Santo Elesbão, 
Santa Efigênia e Nossa Senhora do Rosário ${ }^{4}$. Isto me permitiu constatar que os santos negros não são portadores apenas de hagiografias, mas também de geografias. As versões sobre as histórias de vida desses santos presentes nas paisagens internas de igrejas, como nos seus altares e afrescos, serviram de projeção para que os sujeitos negros que participaram da construção de Ouro Preto pudessem se manter vivos enquanto coletividade num contexto em que tudo apontava para sua reificação e desumanização. Ao serem articuladas a espaços da cidade, as biografias de Antônio de Noto, Benedito, Elesbão e Efigênia criaram lugares onde se podia territorializar a vida, ainda que por via simbólica. Para sujeitos em que tudo era insólito, alguma fixidez e referência espacial podia marcar uma forma de enraizamento para se cultivar a vida compartilhada. Esse traço simbólico parece ter perdurado e ser um indicativo de como esses grupos africanos e afrodescendentes puderam, a partir de negociações e reinvenções, permanecer no tempo e no espaço. Tanto isso é verdade que na contemporaneidade são esses espaços que servem de referência para que coletividades negras em Ouro Preto encontrem direções para organização de suas memórias, como é o caso das festas de Congado.

Outra dimensão positiva das identidades negras relacionadas a Ouro Preto pode ser identificada a partir de representações da figura mítica de Chico Rei, considerando o modo como sua imagem aparece em diferentes suportes artísticos e performances orais e festivas. Chico Rei é um personagem da tradição oral que recorrentemente aparece nas narrativas congadeiras como tendo sido o responsável pela implementação do Congado no Brasil. De acordo com essas narrativas, Galanga - batizado como Chico após sua escravização -, foi um monarca nascido no Congo, submetido e escravizado a partir do tráfico engendrado pelos europeus, que no Brasil trabalhou forçadamente na mineração e que a partir desse trabalho conseguiu criar estratégias para compra de sua alforria e de outros escravizados. Com essa reconquista da liberdade, Galanga teria sido coroado cerimonialmente no Brasil, dando início às festas de coroação de reis negros em Minas Gerais. Das diversas narrativas que pude escutar de congadeiros em diferentes partes de Minas Gerais, Ouro Preto é apontada como sendo o centro geográfico do acontecimento desse episódio.

Essa recuperação da imagem de Chico Rei ajuda a pensar como sua ligação com Ouro Preto acabou por torná-la uma cidade considerada berço das festas de Congado no

\footnotetext{
${ }^{4}$ Os templos nos quais realizei etnografias dos percursos foram: a Igreja de Nossa Senhora do Rosário dos Homens Pretos, no Pilar; a Igreja de Santa Efigênia, no Alto da Cruz; e a Capela de Nossa Senhora do Rosário, no Padre Faria.
} 
Brasil, com alguns espaços da cidade se constituindo pretensamente em testemunhos concretos de sua dimensão mítica. Examinando o aparecimento de Chico Rei em diferentes suportes narrativos ${ }^{5}$ é possível notar como o personagem se tornou uma figura divulgada e circulante através de instrumentos que levaram a trajetória de Galanga para diversos lugares e pessoas. Essas versões sobre o mito, além de divulgarem traços da vida do monarca negro, contribuíram para produzir densidades simbólicas para os espaços a ele associados. Pela circulação das imagens produzidas pelos poemas, romance, filme, desfiles carnavalescos, performances orais e festivas, não apenas histórias sobre um personagem foram difundidas, mas também lugares foram destacados por participarem dessa trama. Sejam factuais ou ficcionais, as versões sobre a trajetória de Chico Rei foram elaboradas a partir de referenciais históricos e geográficos concretos e talvez seja isso que dê maior alcance ao mito. Se Galanga foi figurado num contexto temporal e espacial que admitimos como sendo real, relacionado com o ciclo do ouro em Minas Gerais, como não seria também ele portador de uma concretude? Assim, é possível que visitemos os espaços onde se desenvolveu a história de Chico Rei. A ladeira e a Igreja de Santa Efigênia e a Mina de Chico Rei são lugares acessíveis a todos aqueles que visitam Ouro Preto. Após ler Cecília Meireles e Agripa Vasconcelos, assistir ao filme de Walter Lima Júnior, participar de uma festa de coroação de reis negros, conversar com um congadeiro, ler os relatos de um folclorista e escutar a um samba do Salgueiro ou da Mangueira, como é possível estar em um dos espaços relacionados às histórias de Chico Rei e não sentir emocionalmente sua presença na conformação daqueles lugares e paisagens? Conforme Silva (2007), o mito de Chico Rei é, então, atualizado na contemporaneidade a partir de narrativas que tornaram sua trajetória localizável espacialmente, o que nos permite pensar Chico Rei como um mito espacializado.

Assim, ao mesmo tempo em que a paisagem de Ouro Preto possui um conjunto de narrativas excludentes que concorrem para tornar hegemônicas algumas identidades privilegiadas, as narrativas de liberdade relacionadas com as referências negras também estão ancoradas em lugares. Dividindo espaço com imagens que reduzem as identidades dos povos negros, esses lugares dão substância para movimentos que buscam ressaltar os outros aspectos da negritude para além daqueles já consagrados pelos discursos

\footnotetext{
${ }^{5}$ As obras analisadas para a pesquisa foram: Romanceiro da Inconfidência, de Cecília Meireles, de 1953; Chico Rei - Romance do ciclo da escravidão nas Gerais, de Agripa Vasconcelos, de 1966; Chico Rei - um filme sobre a liberdade, de Walter Lima Júnior, de 1986; o enredo O sonho dourado de Chico Rei, da Escola de Samba Acadêmicos do Salgueiro, de 1964; o enredo A festança brasileira cai no samba, da Estação Primeira de Mangueira, de 2014.
} 
oficiais e que geralmente são estruturados de forma a deslegitimar o modo de vida daqueles que não atendem a um ideal e padrão de corpo que corresponde ao que é concebido como sendo belo, portador de sabedoria, de capacidade intelectual, de agência política e mesmo de humanidade. Poder reconhecer na paisagem um discurso afirmativo da positividade da negritude é, como veremos mais adiante, uma possibilidade de demarcação de paisagens racializadas e lugares com densidades simbólicas que dão força aos movimentos de reconhecimento de uma herança histórica e cultural afrobrasileira.

\section{OURO PRETO: CIDADE E(M) FESTA}

Além de ter figurado como referência para projeção da memória nacional e para as representações de racialidade, Ouro Preto também é um marco simbólico para diversos outros grupos sociais. Esse fato faz com que Ouro Preto, além de se constituir num lugar simbólico, possa ser tomada como uma cidade que abriga uma série de itinerários que através de rituais, festas, festivais e outros eventos -, trabalham na manutenção ou reconstrução de simbolismos. Carnavais, Semana Santa, Festa da Pátria, Reinados, festas de santo, festivais de arte são exemplos desses itinerários que atualmente ocorrem na cidade em função de sua espessura histórica.

$\mathrm{Na}$ condição de cidade formada no período colonial, Ouro Preto concentrou e participou da produção de festas formuladas a partir de referenciais étnico-culturais diversificados e ligadas a diferentes segmentos de poder. Seu espaço urbano, ao longo do tempo, foi lugar privilegiado para a constituição de rituais de afirmação e contestação política, de festas de caráter sagrado e profano, de eventos das culturas eruditas e populares, de celebrações da alegria e da dor. $O$ caráter cerimonial que esse espaço ganhou faz com que para conhecer qualquer realidade festiva em Ouro Preto seja necessário tocar nas demais festas que têm a cidade como lócus. Ouro Preto congrega, dessa forma, uma constelação de festas. Embora cada festa seja marcada por características e fundamentos específicos, elas estão fatalmente envolvidas umas com as outras, fazendo com elas se impliquem mutuamente. E a conexão maior existente entre elas parece ser o fato de todas partirem de um espaço comum, seja para afirmar esse espaço ou contestar elementos que o compõem.

Para as cidades de antiga mineração, é possível dizer que as procissões e as festas religiosas estiveram entre os principais elementos envolvidos com o seu surgimento. Para uma dinâmica social que reunia referências de diversos povos e que 
buscava encontrar um formato próprio de estruturação, esses eventos funcionaram como um instrumento potente. Eles contribuíram para a marcação do tempo social, para a constituição das identidades espaciais e para o estabelecimento ou reforço de hierarquias. (PEREZ, 2002)

Podemos encontrar diversos indicativos que apontam para a dimensão festiva que possuíam as Minas Gerais dos séculos XVIII e XIX, período em que o estado conheceu o apogeu da economia mineradora e seus desdobramentos. Ao recuperar os relatos dos viajantes naturalistas nas Minas oitocentistas, Perez (2009) comenta que apesar de não ter sido objeto privilegiado dos estrangeiros que visitavam o Brasil, as festas figuraram como assunto de destaque de muitos dos relatos por eles elaborados. Ao transitarem pelas vilas, aldeias e arraiais, esses viajantes esbarravam em festas e se admiravam com sua quantidade, exuberância e duração. Públicas e privadas, cívicas e religiosas, e vinculadas a diferentes grupos étnico-raciais, as festas mineiras despertaram a percepção do olhar europeu, que se impressionava com um calendário povoado por tantos eventos.

Examinando os relatos e estudos sobre Ouro Preto desde sua condição de vila até o período mais recente, podemos notar que as festas se desenvolveram na cidade como uma forma de comunicação. Elementos como os toques dos sinos, as procissões, os enfeites de fachadas de casas e a elaboração de altares, podem ser pensados como formas de exteriorizar a vida e estabelecer trocas de valores, experiências e ideias. A esse respeito, Furtado (1997) apresenta como as procissões festivas nas Minas setecentistas se constituíram como um dos principais mecanismos de reforço dos laços sociais da sociedade colonial. Ao ocupar o espaço das ruas e praças e tomar uma forma processional, essas festas acabavam por transformar momentaneamente a paisagem das cidades da mineração marcadas pelo ritmo plácido. A partir do exagero e do fausto, expresso nas vestimentas e objetos rituais, os valores e símbolos do colonizador foram direcionados para as diferentes camadas sociais, o que concorreu para a normatização de comportamentos e reforço de hierarquias.

Para além dos rituais mais ligados aos círculos de alto poder em que os eventos festivos eram geralmente utilizados para exposição das elevadas posições na hierarquia social - como o Triunfo Eucarístico e as Exéquias de Dom João $V$ que tiveram acontecimento em Ouro Preto no Setecentos e que ainda são lembrados pelo seu esplendor -, também as festas das irmandades possuíam especial destaque no período áureo da cidade, transformando profundamente sua rotina para que os santos celebrados ganhassem evidência. Santo Antônio, São Pedro, São Gonçalo do Amarante, a Imaculada 
Conceição, São Jorge, São Sebastião e São João eram aí figuras frequentes das várias festas das irmandades. Merecem destaque, porém, as festas relacionadas às irmandades negras. Para Ouro Preto, Viana (2012) chama atenção especialmente para as festas das Irmandades do Rosário, pela grande concentração de devoções que congregavam. Celebrando São Benedito, Santo Antônio de Noto, Santo Elesbão e Santa Efigênia, e coroando seus próprios reis, as festas ligadas a esses santos ganhavam especial destaque por serem a possibilidade principal para que a população escravizada acessasse os lugares públicos da cidade em caráter ritualístico.

Todo esse fulgor festivo, apesar das interrupções em determinadas manifestações em função das mudanças sociais, permaneceram constituindo a identidade territorial e ritmando a vida social ouro-pretana. Novos festejos surgiram pela cidade, alguns dos antigos foram se transformando e outros permaneceram vivos na memória. Dessa forma, diversos festejos continuam a figurar no calendário da cidade, mobilizando diversas pessoas que ainda contemporaneamente investem grande energia para que essas festas tenham seu acontecimento. Esse envolvimento atual com as festas não parece ser mobilizado, porém, apenas para que esses festejos não caiam no esquecimento, mas porque elas são parte fundamental da vida das pessoas e de suas relações com a cidade.

Durante a realização da pesquisa pude observar parte considerável dessas festas. De algumas delas participei, inclusive, como festeiro. Embora para essas festas e rituais eu não tenha produzido uma densidade de informações capaz de permitir uma interpretação mais apurada, compreendo que o contato com estudos relacionados a três delas contribui para o entendimento da relação que as festas do Congado possuem com a cidade na contemporaneidade.

A Semana da Inconfidência, primeiro desses eventos, se constitui como uma solenidade cívica comemorativa da Conjuração Mineira. Seu ato principal acontece no encerramento da Semana, no feriado nacional de 21 de abril em que se comemora o Dia de Tiradentes. Nesse dia, o ritual de entrega das comendas é marcado por uma série de discursos políticos que recuperam o acontecimento da Inconfidência para fazer conexões com o tempo presente. A cerimônia representa também a transferência simbólica da capital de Minas Gerais, restituindo ainda que efemeramente essa posição já ocupada por Ouro Preto. A depender da orientação partidária do governador do estado o evento pode ter diferentes feições, com a medalha geralmente confirmando as afinidades políticas do grupo que ocupa o cargo de maior poder em Minas Gerais e o que se desdobra em 
diferentes formas de reação e manifestação dos movimentos sociais em relação ao evento.

Apesar das diferentes orientações e formatos que ganham esse evento a cada ano, permanece em comum o fato de a Semana da Inconfidência ser respaldada pela paisagem colonial de Ouro Preto, uma vez que o ritual se utiliza do capital simbólico que o lugar agregou. Ser um espaço tecido pelo tempo é o que faz daquele lugar uma plataforma. A esse respeito, Rocha (2014), que pesquisou as narrativas produzidas sobre o evento pela grande mídia, sugere que a cenografia da Praça Tiradentes institui uma espécie de dilatação no tempo, eternizando personagens e fazendo com que permaneçam espaços. Assim, a Praça comporta-se como um dispositivo enunciativo que se autoriza a partir de eventos anteriores que nela tiveram sua ocorrência. Haveria, então, um plano de cenografia ali formulado que possibilita a existência da atual solenidade da Semana da Inconfidência. Trata-se, portanto, de um caso na cidade em que um ritual se articula à paisagem para que ganhe densidade e que construa os seus sentidos.

Outro dos rituais contemporâneos de Ouro Preto que possui relevância em função do público que atrai e das imagens da cidade que faz circular é o carnaval. Como ressalta Rosa (2000), o carnaval está dentre os eventos ouro-pretanos responsáveis por gerar os maiores fluxos de pessoas até a cidade. Diversificado em suas formas de manifestação, o carnaval em Ouro Preto há décadas conjuga o desfile de blocos caricatos, os cordões e o carnaval de rua. A pesquisa da autora indica ainda como a paisagem patrimonial da cidade se constitui como um dos principais interesses que movem os visitantes que optam pela participação na festa. Ao se somar aos corpos em movimento e aos deslocamentos do carnaval, as fachadas da arquitetura barroca ajudam a criar uma experiência específica para a festa ali ocorrida atrelada ao cenário que a comporta.

Em estudo mais recente, Mayor (2013) atualiza reflexões sobre essa relevância ganhada pela paisagem na configuração do carnaval ouro-pretano. Considerando o papel desempenhado pelo mercado nas atividades de lazer nas décadas recentes e a maneira como os carnavais se articularam com essa mudança no panorama das festas, a autora indica como isso adquiriu um caráter específico em Ouro Preto, cidade que passou por grande investimento para torná-la o principal carnaval de Minas Gerais e um dos mais destacados do interior do Brasil. Essa imagem, que começou a ser criada na década de 1980 e ganhou maior visibilidade nas décadas seguintes, foi construída a partir da evocação de um imaginário de passado da cidade que a conferia uma especificidade. Em um panorama nacional em que as festas carnavalescas passaram a se tornar cada vez 
mais semelhantes com a expansão da música e dos ritmos baianos do axé music, apresentar um cenário que não se repetia em outro lugar era fator de atração. A festa que se caracterizou por ser essencialmente de rua, começou a dividir espaço com eventos em espaços fechados que, apesar de se vender por uma imagem de tradicional, buscava repetir aquilo que era comum de um carnaval mercantilizado. Assim, nas diferentes dimensões do carnaval ouro-pretano, a paisagem barroca e as camadas simbólicas que produziram aquele lugar também acabaram por se vincular aos sentidos da festa, sendo a espacialidade um dos elementos centrais recuperados para produzir os seus significados.

Mais um dos eventos festivos que têm acontecimento em Ouro Preto é a Semana Santa. Tal como os dois últimos eventos apontados, esse ritual atualmente também amalgama a festa e as especificidades da cidade. A Semana Santa ocorrida em Ouro Preto possui os mesmos aspectos gerais de tantas outras celebrações da morte e ressurreição de Cristo realizadas a cada ano em inúmeras cidades do Brasil nas proximidades da Páscoa. Pereira (2016), ao apresentar sua interpretação do ritual, indica, porém, que a encenação da morte e ressurreição de Cristo ocorrida em Ouro Preto possui particularidades pela maneira como ela se comunica com os espaços, materialidades e eventos relacionados aos bens patrimonializados pelo IPHAN, caso das igrejas barrocas e das imagens artísticas relacionadas a um relevante personagem da cidade: Tiradentes.

Como apresenta o pesquisador, a Semana Santa ouro-pretana, ao se utilizar das imagens barrocas com a representação de Cristo e de outras figuras religiosas, acaba por reforçar um caráter "tradicional da festa" e reclamar uma "profundidade histórica" do evento. Os bens patrimoniais que constituem a paisagem, como as imagens sacras e os passos que compõem o trajeto da via-crúcis, realçam uma especificidade da festa ali existente. Em função de os objetos e percursos rituais que são utilizados na festa serem os mesmos que serviram para a construção do ritual por tantos séculos, isso confere uma aura de tradicionalidade que não pode ser repetida no festejo de qualquer outra cidade. Soma-se a esse fato, conforme Pereira (2016), as continuidades que são concebidas entre as figuras de Cristo e de Tiradentes. As imagens de dor e sofrimento manejadas na procissão e o cortejo com as imagens em que é encenado e narrado o episódio da paixão e morte de Cristo, faz mesmo com que uma espécie de transe crie uma fusão e confusão entre os dois personagens. Em razão da existência histórica de Tiradentes coincidir com a origem das imagens barrocas setecentistas, sua biografia articula mais um elemento que confere a tradicionalidade da festa. 
Desse modo, a Semana da Inconfidência, o Carnaval e a Semana Santa, ainda que guardadas suas lógicas próprias de funcionamento, possuem o aspecto comum de estabelecer um amálgama entre sua dinâmica e o seu espaço de acontecimento. Mais do que simplesmente um cenário, elas se comunicam com uma paisagem e constroem parte de sua legitimidade a partir do respaldo que o lugar simbólico em que se constitui Ouro Preto os fornece. Esses "carnavais, paradas e procissões", pensando como DaMatta (1980), atuam como mecanismos rituais que fazem com que a dinâmica social de Ouro Preto se elabore a partir da articulação de alguns itinerários e lugares simbólicos.

Concebo que esse mesmo tipo de mecanismo festivo é realizado pelo Reinado ${ }^{6} \mathrm{em}$ Ouro Preto. Minha interpretação é a de que o coletivo de pessoas negras que realiza esse festejo compreende o poder que possui a festa naquela cidade como mecanismo de produção de políticas de significados. Cientes de que no plano cotidiano a reelaboração de hierarquias sociais possui maiores entraves, esse grupo de pessoas negras se mobiliza em políticas antirracistas para articular mudanças que operam no nível do simbólico. Sem superdimensionar um aspecto político para essas festas do Congado, visto que elas possuem em sua fundação um aspecto de religiosidade e diversão, penso ser possível sugerir que essas festas possuem impactos na reorganização na ordem social ao se realizarem. Assim, elas conseguem, a partir de sua dimensão de regozijo, alegria, transcendência e lazer, tratar de temas determinantes do cotidiano das pessoas que a produzem a partir da imaginação e alucinação simbólica que a festa permite (DUVIGNAUD, 1983). É essa a concepção que desenvolvo na seção seguinte do texto.

\section{LUGARES E ITINERÁRIOS SIMBÓLICOS NO REINADO DO ALTO DA CRUZ}

Efetivando-se a partir de performances rituais no interior de igrejas e de cortejos públicos em devoção a Nossa Senhora do Rosário e aos santos negros, os festejos de Congado elaboram e comunicam narrativas que informam e atualizam memórias sobre as diásporas africanas pelo mundo e as histórias de contatos culturais entre distintos povos no território brasileiro. Com acontecimento em diversas cidades de Minas Gerais e de outros estados brasileiros, como Goiás e São Paulo, os Congados elaboram um "teatro sagrado" com uma complexa estrutura que envolve a realização de atos devocionais, cortejos e embaixadas, o levantamento de mastros, a execução de autos e danças dramáticas, a coroação de reis e rainhas, o cumprimento de promessas e a elaboração de

\footnotetext{
${ }^{6}$ Reinado é o nome que recebe o principal evento festivo relacionado à coroação de reis e rainhas negros.
} 
atos litúrgicos cerimoniais e cênicos por pessoas negras católicas e/ou vinculados a outras religiões.

Como indica Souza (2002), os registros apontam que as festas de coroação de reis negros estão presentes no Brasil desde o século XVII, tendo se formado a partir do encontro violento entre a cultura portuguesa e de diversas nações africanas. Inicialmente, as coroações ocorreram no interior de irmandades negras como uma estratégia para reconfiguração das identidades dilaceradas pelo traumático processo de passagem transatlântica. Nesse sentido, vale registrar que muitos dos povos negros que no Brasil foram colocados em convívio na condição de escravizados pertenciam a nações, referenciais culturais e idiomas muito diversos. A festa foi uma possibilidade de agregar pessoas com histórias diferentes que compartilhavam algumas trajetórias em comum.

Após a abolição da escravatura, as festas de Congado continuaram com alguns de seus principais elementos rituais. Nos cortejos pelas ruas de pequenas e grandes cidades que a festa atualmente realiza, a narrativa espacial "encenada" e revivida informa sobre a liberdade do negro no continente africano e sua posterior escravização, sua traumática passagem transatlântica, seu sofrimento no cativeiro no Brasil e sua recuperação da liberdade (MARTINS, 1997). Isso faz com que o Congado possa ser compreendido como uma crônica social que representa, reapresenta e examina a configuração dos lugares e tempos dos povos negros em suas diásporas (DIAS, 2001).

Em Ouro Preto, as cerimônias do Congado se formularam desde a constituição da cidade. Aspectos que atestam essa longevidade histórica podem ser encontrados em documentos datados desde o início do século $\mathrm{XIX}^{7}$. O que informam os congadeiros e congadeiras do Alto da Cruz de Ouro Preto ${ }^{8}$ é que a festa se elaborou naquele território no período da escravidão, com suas narrativas sempre remontando à figura de Chico Rei como o responsável por sua implantação. Os atuais congadeiros ouro-pretanos dizem ter conhecimento ainda da presença contínua do Congado na cidade, mas que o festejo de coroação de reis negros por muito tempo deixou de ocorrer. O que havia era um grupo de Congado que participava das festividades de outros municípios ou uma festa local de

\footnotetext{
${ }^{7}$ Dell'aira (2009) identificou registros do Congado em obras dos viajantes estrangeiros que estiveram em Minas Gerais. O autor destaca a litografia de Rugendas, que elaborou na prancha Fête de Ste Rasaile, Patrone de Négres cuidadosa representação de um ritual de coroação de reis negros que teria ocorrido em Ouro Preto entre os anos de 1824 e 1825.

8 Vale destacar que na sede do município existem, além dos grupos do Alto da Cruz, mais dois Congados formados nos anos 2000: O Congado de N. S. das Graças e a Guarda de Congo Manto Azul de N. S. Aparecida. Nos distritos ouro-pretanos há ainda dois grupos de história mais antiga, o Congado de Santo Antônio do Salto e o de Miguel Burnier. As observações participantes e as entrevistas que realizei foram feitas principalmente junto ao Congado de N. S. do Rosário e Santa Efigênia do Alto da Cruz, sendo este o responsável pela realização do Reinado de que trata a pesquisa.
} 
menores proporções até a década de 1980, mas que por motivos desconhecidos foi interrompida. O Reinado, como ocorre atualmente, foi elaborado apenas na passagem entre os anos de 2008 e 2009, quando os congadeiros ouro-pretanos se mobilizaram em torno da necessidade de que houvesse uma festa de Congado na cidade onde viveu Chico Rei.

A existência contemporânea do Congado em Ouro Preto é fruto, portanto, da conexão entre diversas trajetórias. Como relatam os congadeiros, foi a partir da aproximação entre um antigo grupo, marcado por uma história de migrações relacionadas aos ciclos econômicos de Minas Gerais, com novos sujeitos que se associaram a ele a partir dos anos 2000, que a festa ganhou sua feição atual. Assim, os sujeitos que atualmente realizam o Reinado em Ouro Preto sustentam uma narrativa sobre a existência de uma história de apogeu, decadência e renascimento, demarcando que seria justamente esse caráter histórico e mítico daquela festa que a conferiria tanto destaque.

O que é interessante observar é que embora em sua forma atual o Reinado seja um evento recente em Ouro Preto, ele rapidamente mobilizou um grande número de grupos que se deslocam para vivenciarem a festa. Desde o seu segundo ano de acontecimento ele conta com cerca de 40 grupos visitantes. Observando outros Reinados mineiros, é raro ver festejos com essa dimensão.

Conversando com capitães de Congados de outras cidades sobre suas presenças nas festas de Ouro Preto, eles apontam que suas frequências ao evento se relacionam com a expectativa de visitar o Reinado que tem sua ocorrência proveniente do próprio Chico Rei e pelo caráter histórico da cidade e da festa. As falas que indicam essa longevidade do Reinado mencionam o cenário barroco e colonial como um confirmador dessa marca temporal. Assim, embora o Reinado ouro-pretano tenha se elaborado tão recentemente, ele já nasce com uma chancela de "tradicional".

Além dessa característica de mobilizar eficientemente imagens de tradição e renovação, o Congado em Ouro Preto apresenta alguns elementos bastante diferenciados em relação a outros grupos. Em termos da elaboração dos rituais, os atos que configuram a Semana do Reinado não são constituídos apenas por momentos de celebração aos santos, como acontece em muitos outros Congados a partir da realização de novenas. Os momentos devocionais ocorrem apenas na abertura da semana festiva do Congado, nos três dias que antecedem ao Reinado e no domingo festivo. Os outros dias que compõem a estrutura da festa são preenchidos por palestras e oficinas que, de acordo com o Rei Congo do grupo, servem para instruir os congadeiros sobre questões importantes. Essas 
palestras e oficinas costumam abordar temas relacionados com a cultura afro-brasileira e convida autoridades acadêmicas ou rituais para que as realizem. Nos anos que observei a festa, entre 2013 e 2017, foram convidados professores de programas de pós-graduação, juízes, pais de santo, dentre outras autoridades, para discorrer sobre temas como religiões de matriz africana, modos de denúncia do racismo e da injúria racial, poesia negra, patrimônio cultural, situação da mulher negra no Brasil, dentre outros. Relevante destacar ainda que há uma média de idade entre seus membros menor do que pude visualizar em grande parte de outros Congados em Minas Gerais. Jovens, adolescentes e crianças constituem a maioria dos congadeiros ouro-pretanos. Alguns dos componentes do Congado atuam como funcionários de órgãos relacionados com as políticas culturais na cidade, possuindo inclusive influência em alguns desses órgãos, como o Museu da Inconfidência, a Secretaria Municipal de Turismo e a Câmara Municipal.

Divergindo também da maioria de outros Congados, o Reinado de Ouro Preto ocorre no ciclo natalino, iniciando no primeiro domingo do mês de janeiro - com o levantamento dos mastros em homenagem a Nossa Senhora do Rosário, Santa Efigênia e São Benedito -, e se encerra, sete dias depois, com o descendimento desses mastros após a realização da Missa Conga durante o domingo festivo. É assim que, no início de cada ano e pela extensão de uma semana, os congadeiros e congadeiras se reúnem para celebrar seus santos de devoção nas proximidades do bairro do Alto da Cruz. No intervalo entre os dois domingos, uma série de ações rituais compõe uma estrutura festiva que torna mais variado o conjunto de cores que cotidianamente marca o tom do casario colonial do centro histórico ouro-pretano, a partir do enfeite das fachadas de casas e da colocação de bandeirolas pelas ruas por onde a festa se desloca. Essa alteração de paisagem ocorre ainda para eventos mais efêmeros, a partir da montagem de altares nas janelas e sacadas de casas e do acontecimento dos cortejos e procissões que em conjunto constituem a paisagem festiva. Acompanhando essa mudança na paisagem visível do bairro, os tambores e outros instrumentos sonoros do Congado, além dos sinos das igrejas localizadas pelos trechos que a festa percorre, ritmam de outro modo a passagem do tempo pelas ladeiras e becos situados entre a Mina de Chico Rei e a Capela do Padre Faria. Com a chegada de cerca de mil e quinhentos congadeiros à cidade e dos visitantes associados à festa, outros corpos, formas de circulação e sociabilidade passam a marcar o movimento das ruas em que o Reinado tem seu acontecimento. 
Os grupos que excursionam até Ouro Preto vão, então, de encontro aos espaços que servem de referência para a história de Chico Rei. A figura 1 apresenta a diversidade de grupos que nos anos recentes vêm visitando o Reinado e os longos deslocamentos que realizam, o que indica como o Congado do Alto da Cruz tem sido capaz de capitalizar a trajetória simbólica do seu lugar de pertencimento de modo a fazer de seu Reinado um espaço de acesso a um passado memorial que desperta o interesse para frequência à sua festa de um número destacado de congadeiros.

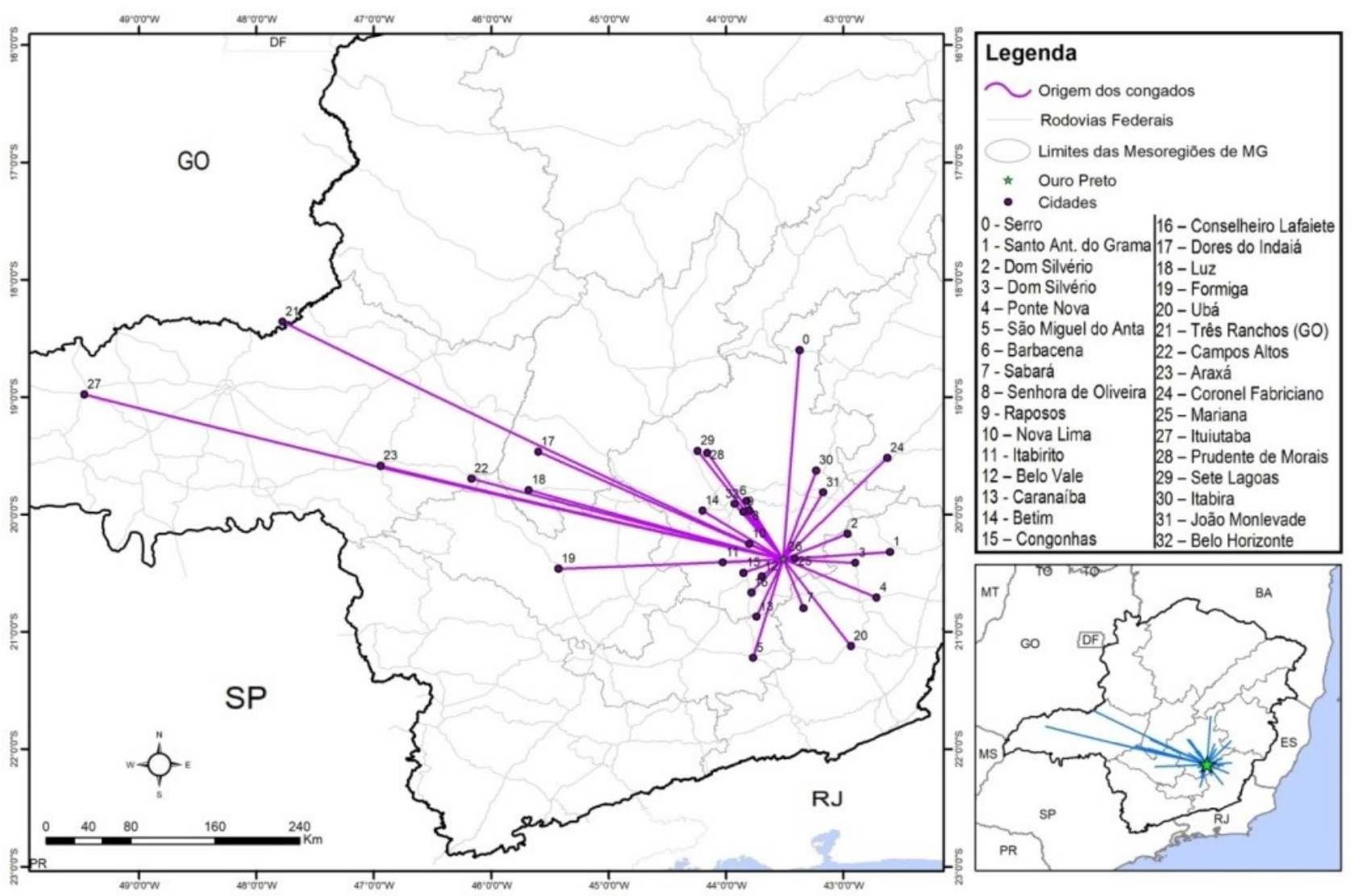

Figura 1 - Municípios de Origem dos Congados que se dirigem a Ouro Preto para o Reinado9

Fonte: Elaborado pelo autor, 2018.

Ao nos concentrarmos na "retomada" do Congado ouro-pretano no século XXI, é possível afirmar, então, que sua importância é demarcada a partir da rede de relações que o grupo tem configurado com suas participações em outras festas de Congado pelo estado e a consequente retribuição pelas visitas que realiza. Assim, ainda que os congadeiros do Alto da Cruz não visitem todos aqueles grupos que recebem, eles são eficazes no estabelecimento de contatos nos Reinados que participam. Muitos guardas

${ }^{9} \mathrm{O}$ registro desses grupos foi feito a partir do meu trabalho de campo, o que me permitiu constatar que eles são mais ou menos constantes. As variações são ocorridas pela visita de novos grupos ou pela ausência em determinado ano de algum que costuma ser frequente. Vale destacar que algumas das cidades registradas possuem mais de um grupo de Congado, fazendo com que a figura revele as origens municipais ao invés da diversidade de grupos. 
que vão à Ouro Preto dizem ter conhecido aquele grupo no grande encontro de Congados em Aparecida, São Paulo, ou em outros festejos em que eram visitantes. Desse modo, ao produzirem laços sociais e territoriais com diversas guardas em Minas Gerais nos Reinados que participam ou na comunicação através da internet, os congadeiros do Alto da Cruz estabelecem uma rede comunitária que permite a divulgação e reforça as camadas simbólicas que Ouro Preto possui em função das memórias negras que abriga.

Podemos conceber, portanto, que ao tornar o seu festejo um lugar de atração para tantos congadeiros e fazer daquela festa uma concentração de pessoas negras na posição de sujeitos altivos, os Reinados do Alto da Cruz lançam mão de ações estratégicas de uso do espaço que atuam na transformação representacional (MASSEY, 2008). Ao ocupar o espaço de ruas relevantes para a história dos povos negros, de igrejas onde santos de devoção negra são celebrados, de sítios onde se desenvolveram experiências de resistência à escravização ou mesmo se fazendo presentes em rituais de coroação de reis negros em espaços da cidade em que os elementos patrimoniais comunicam uma estética de sofrimento do negro escravizado, essas festas criam perturbações na narrativa que o patrimônio edificado e os rituais a ela relacionados buscam perpetuar.

Assim, uma paisagem que durante o tempo cotidiano atua para submeter, nos momentos festivos do Reinado é utilizada para qualificar. Isso ocorre porque, embora demarquem pontos de referência a partir de algumas igrejas, os Reinados têm sua dinâmica principalmente na rua. É nos cortejos que elas encontram seu ápice e momento catártico, porque é na rua que elas comunicam as narrativas espaciais que ritualmente reapresentam. Mesmo quando as ações são realizadas em maior conexão com a religião oficial, os congadeiros conseguem fazer com que se confundam a dimensão da rua e os espaços restritos das igrejas. Não é um acaso que as bênçãos, missas campais e mastros levantados sejam uma forma de fusão entre a rua e o espaço circunscrito do catolicismo oficial. Daí a preferência por escadarias, adros e entornos das igrejas ao invés do seu interior. A festa do Congado é sempre expansão, seja do sagrado ou dos valores da negritude que ela amplia.

Mais um elemento que indica como o grupo de Congado tem se organizado de modo a impactar nas concepções hegemônicas de negritude na cidade, diz respeito à ação dos congadeiros de realizar um direcionamento da atenção para uma determinada parte da cidade ao invés de praticar um enfrentamento direto junto aos espaços em que não há uma positividade na representação do negro. Embora eu tenha presenciado o 
Congado em atividade nesses espaços - como uma situação em que o grupo proferiu cantos enquanto a festa passava pelo Museu da Inconfidência questionando o protagonismo de Tiradentes e reivindicando a representação de Chico Rei -, o Reinado é pertencente a uma parte da cidade. É nas proximidades da materialidade com a qual Chico Rei teria tido contato, como a Mina que leva seu nome e a Igreja de Santa Efigênia, que a festa tem o seu acontecimento. Assim, a ação de ressignificação que o grupo constrói possui mais relação com a criação de uma densidade de eventos para uma porção de Ouro Preto que costuma ser secundarizada nos trajetos turísticos, do que em atrair mais olhares para aquilo que já se encontra estabelecido. As ações de contraposição às representações dos museus são realizadas via palestras e oficinas que ocorrem durante a Semana do Reinado. Ao principal dia festivo é resguardado o momento para colocar em evidência aqueles símbolos negros que, apesar de constituírem a paisagem simbólica ouro-pretana, estão dispersos e menos evidenciados. Assim, limitar a festa a determinados espaços é um forma de demarcar territórios, paisagens e lugares prioritários para o Congado em Ouro Preto.

A maneira de participar dessa demarcação simbólica se dá a partir da experiência emocional de paisagem que a festa elabora, envolvendo uma marcação de lugar a partir do sabor do alimento que é servido, da criação de sonoridade a partir do toque marcante do tambor ou de uma ambientação olfativa a partir dos aromatizantes utilizados na benção da escadaria da Igreja onde é celebrada parte da festa. É possível sugerir, desse modo, que emoções rituais se formulam a partir das interações espaciais que os Reinados promovem. Nesses rituais a emoção e o afeto expressos a partir de gestos e ações são responsáveis por transformar o mundo. $\mathrm{Na}$ impossibilidade de reconfigurar o patrimônio de "pedra e cal" de forma objetiva, as vivências permitidas pelos rituais do Congado viabilizam que os congadeiros possam ao menos conferir a essas materialidades outras qualidades a partir da emoção ritual. Os deslocamentos e apropriações espaciais que as festas promovem possibilitam, desse modo, que interferências nas representações e imaginários possam ser realizados, provocando a contestação e a revisão de certos aspectos estabelecidos e permitindo outras perspectivas sobre determinadas questões. Trata-se, portanto, de um modo de lidar com o mundo a partir do encantamento, em que um espaço geométrico - onde as distâncias são fixas e as espacialidades são objetivas -, é convertido em um espaço emocional - em que dispositivos subjetivos e eivados de afetividade passam a ser preponderantes (MAIA, 2011; 2010). 
Podemos admitir, dessa maneira, que a profusão de cores, sabores, cheiros e sons, associada a marcos como portais e o uso de elementos como bandeiras e mastros, produz uma paisagem com outras qualidades que fazem sentido no momento da festa. Tais paisagens, ainda que efêmeras, permitem que sua a materialidade seja concebida mais do que apenas como uma herança histórica ou como uma história congelada, se tornando também uma convergência do mundo vivido (MAIA, 2011). Assim, o Congado realiza uma espécie de "descongelamento" da paisagem, para assumi-la como uma dimensão que também é produzida e requalificada pelas ações e interações mediadas pela emoção. Para uma festa como o Reinado, essa concepção ajuda a pensar a maneira como o seu acontecimento provoca interferências na paisagem grandiloquente como a do centro histórico de Ouro Preto, à qual o ritual produz uma transformação via encantamento. Ao deslocar santos negros e objetos cerimoniais, manipulando sua potência e gestando seus poderes e biografias, a festa ajuda a reinventar o mundo, fundindo forma e conteúdo para a elaboração de paisagens que não são apenas histórias e geografias cristalizadas, mas também temporalidades e espacialidades vivas e contingentes que permitem um redimensionamento das relações.

Assim, a Igreja de Santa Efigênia, a Capela do Padre Faria e a Mina de Chico Rei, além de serem referências para o grupo do Alto da Cruz, também são de relevância porque produzem efeitos simbólicos em relação à imagem da negritude, inclusive para aqueles que não são ouro-pretanos ou que não são congadeiros. Os festeiros que vêm de outras cidades e são despertados pelo conjunto patrimonializado, ao acessarem essa paisagem a partir do interior da festa, passam por uma espécie de "educação patrimonial" realizada pelos congadeiros ouro-pretanos, ao serem estimulados a olhar e sentir aquela paisagem a partir de um referencial mítico e cosmológico da negritude altiva representada por Chico Rei e pelos santos negros.

Do mesmo modo, as festas do Congado geram para os moradores e turistas de Ouro Preto outras impressões da cidade a partir do seu acontecimento, ao apontar para outro tipo de relação com as identidades representadas nas cenas permanentemente expostas no centro histórico. Esse fato sinaliza sobre o despertar do interesse da população ouro-pretana para imagens da negritude que até recentemente não possuíam centralidade. Também a população escolar e turística que visita a cidade tem possibilidade de se atentar para paisagens patrimoniais que revelam a participação das populações negras no Brasil para além da escravidão. As oficinas e palestras realizadas durante a Semana do Reinado que contam com a presença de universitários, a surpresa 
que a festa causa aos turistas e as apresentações artísticas que os congadeiros realizam em hotéis e pousadas, são responsáveis por difundir os fundamentos do Congado para um público cada vez mais amplo, ressaltando, a partir da circulação de suas imagens e discursos, a concepção de negritude que o grupo possui.

Durante a pesquisa também foi possível notar o aumento da participação do Congado junto às ações de instituições ligadas ao turismo, à universidade, aos órgãos patrimoniais e do poder público municipal. Elementos como a participação do Congado no oferecimento de uma oficina na programação do Seminário Corpo e Patrimônio realizado pelo IPHAN em Ouro Preto em 2014, os constantes convites para que os congadeiros palestrem em escolas e em instituições federais de ensino superior na cidade, a presença de viajantes e universitários na Semana do Reinado impulsionados pela divulgação da festa feita por hotéis e serviços de atendimento ao turista, são elementos que indicam como o Reinado tem ganhado uma potência cada vez maior na veiculação das imagens que sustenta sobre a negritude.

A notoriedade que o grupo vem ganhando pode ser indicada ainda por outros elementos, como a cobertura midiática que com o passar dos anos tem se dirigido ao Reinado. Rádios, TVs e impressos locais, redes de televisão pública do estado sediadas na capital, veículos jornalísticos de cidades vizinhas, redes de televisão estrangeiras, documentaristas, mídias comunitárias e alternativas, se ocupam a cada festa de divulgar e fazer circular suas imagens. Merece destaque ainda a grande circulação de imagens da festa a partir da internet e suas redes sociais.

Desse modo, o acompanhamento aos festejos do Congado permitiu compreender que os sujeitos negros na contemporaneidade de Ouro Preto não são passivos aos processos de redução de suas identidades, mas que disputam a partir dos elementos produtores da paisagem seu reconhecimento como agentes ativos, altivos e pensantes, logo, produtores de suas próprias histórias e geografias. Agindo desse modo os congadeiros acabam por demarcar sua condição pós-colonial, ao colocar em evidência os diferentes encontros entre as sociedades colonizadas e colonizadoras, bem como expondo suas posições sobre as relações coloniais responsáveis por elementos como o racismo e as diásporas. Esses congadeiros reclamam ainda suas participações nas políticas culturais, compreendendo que elas possuem diretas implicações nas dinâmicas relacionadas às questões econômicas e políticas que os atingem. (SHUMER-SMITH, 2008) 
Tanto quanto uma imagem externa da festa, as compreensões sobre os sentidos do "ser negro" também são modificadas pelo Reinado para os próprios congadeiros. A partir das dinâmicas rituais e da percepção dos congadeiros foi possível acompanhar que as subjetividades dos congadeiros são alteradas a partir da realização das festas. Diversos foram os depoimentos que ouvi de como o Reinado oferecia aos congadeiros uma possibilidade de se reconhecer em imagens mais autônomas de negritude do que naquelas veiculadas pela mídia, nos processos escolares e na própria cidade. Um desdobramento disso tem sido o reconhecimento de suas identidades cada vez mais a partir do qualificativo 'negro' do que em categorias como 'moreno' ou 'mulato'. Mudanças significativas também ocorrem em termos do cabelo. Embora muitos dos congadeiros permaneçam com as práticas de alisamento, medida legítima e defendida por muitos deles inclusive como liberdade para que tenham autonomia sobre o controle de seus corpos, a externalização das identidades a partir do cabelo sem a intervenção química tem sido crescente.

O Reinado e toda a dinâmica do Congado participam, desse modo, da produção de uma imagem dos sujeitos negros a partir de referenciais que permitem a produção de discursos sobre si próprios. A relevância dessa dimensão da festa é que ela viabiliza a produção de representações, imaginários e emocionalidades de negritude pelos próprios sujeitos que assumem essa pertença. Assim, mais do que se sentirem estereotipados e terem suas identidades formuladas como um desdobramento de identidades hegemônicas, como a relacionada à branquitude, a construção de uma imagem identitária pode ser feita de forma autônoma e emancipatória. Sujeitos negros e negras participantes dos rituais podem se ver como reis e rainhas coroados e venerados em espaços que cotidianamente não têm essa mesma positividade vinculada ao seus corpos e identidades. Imaginando o novo, tornam essa realidade concreta.

\section{CONSIDERAÇÕES FINAIS}

Ao longo deste texto construí uma argumentação que ressaltou como o lugar simbólico em que se constitui Ouro Preto serve de referência para diversos sujeitos e grupos. Como foi possível conhecer, os processos que dispararam essa singularização da cidade no cenário nacional remontam a mais de três séculos, quando os acontecimentos relacionados como a economia mineradora foram responsáveis por fundar os arraiais e vilas que instituíram uma sociabilidade citadina com poucas correspondências no Brasil colônia. Os desdobramentos dessa vida urbana num país majoritariamente rural 
produziram materialidades que perduraram no tempo. Obras artísticas, construções arquitetônicas, traçados urbanísticos e os registros de mobilizações políticas e manifestações culturais ficaram ali depositados e resistiram às transformações que o país conheceu a partir das avassaladoras mutações políticas, econômicas e sociais.

O pioneirismo da vida urbana de Ouro Preto fez com que séculos mais tarde, quando os interesses políticos do país já se orientavam por outros pressupostos, a cidade fosse eleita como o endereço para corporificar um discurso sobre o Brasil a partir de sua especificidade e sincronismo com as nações modernas. A arte singular e a aspiração de liberdade que nela emergiram em sintonia com os principais valores ocidentais, fez com que o passado da cidade servisse como um símbolo para a fundação de uma identidade nacional. Pelo destaque que Ouro Preto havia desempenhado no passado, mais uma vez sua urbanidade se tornou de relevância. Investimentos em sua memória e imagem foram realizados de modo a torná-la reconhecida pela sua emblemática posição de resguardadora do passado do país. Com essas novas audiências dirigidas à cidade, mais camadas simbólicas foram produzidas de maneira a confirmá-la como um espaço representante da nação.

Como vimos, essa característica que possuem os lugares simbólicos de atrair novas camadas de significados passam a reforçar e confirmar cada vez mais o caráter de singularidade e a potência valorativa daquele espaço. Ouro Preto é, portanto, um lugar que foi sendo tecido pelo tempo. A consequência desse acúmulo de experiências, acontecimentos e emoções direcionados à cidade foi que as representações em relação a ela começaram a se tornar cada vez mais formatadas e estabilizadas. A partir dos investimentos realizados pelas instituições patrimoniais, mecanismos necessitaram se sofisticar para que uma imagem coerente do conjunto monumental ouro-pretano tivesse durabilidade. A elevação pioneira da cidade à categoria de monumento nacional, sua divulgação por diversos meios artísticos e midiáticos, o estímulo aos fluxos turísticos para contato com sua materialidade, seu reconhecimento pelas instituições internacionais de memória, tudo isso acabou por adensar representações, imaginários e emocionalidades calcados em um patrimônio de significados cada vez mais específicos e restritos.

Para o processo de constituição de Ouro Preto como monumento nacional, uma aura de autenticidade e representatividade do caráter nacional deveria ser reforçada por cada parte do conjunto monumental. Assim, as imagens da cidade deveriam participar de uma definição rígida das identidades a serem representadas. Por essa razão, as práticas e rituais responsáveis por confirmar a cidade como portadora dos germes da nação 
demandaram que outras identidades opostas àquela que a memória dominante pretendia se vincular fossem excluídas, negadas ou distorcidas. Ao utilizar de práticas como a construção de metonímias nacionais a partir de objetos que indicavam para um histórico glorioso e majestoso da figura do Inconfidente, outra representação foi simultaneamente sendo produzida, a de um sujeito negro reduzido à escravidão. Desse modo, os arquitetos da memória e os gestores do patrimônio identificaram um número reduzido de objetos e espaços através dos quais a memória nacional pudesse ser representada. A não exposição museal de objetos ligados às iniciativas de altivez e liberdade da numerosa população negra que sempre viveu na cidade ou a insistência de salvaguarda de espaços da negritude relacionados exclusivamente às práticas de escravização, indica que foi selecionado um conjunto limitado de objetos em consonância com o tipo de identidades a que se pretendia cultivar. As materialidades que remetessem aos processos de altivez negra, como os objetos festivos dos rituais de Congado ou registros das insurgências de negros escravizados contra as práticas de trabalho forçado e de negação de sua humanidade, poderiam tornar instáveis certos discursos que se pretendia perpetuar.

Ocorre, porém, que os lugares simbólicos impõem certos limites à fixação de representações exclusivistas. Além de fixar conteúdos dos grupos hegemônicos que detêm os instrumentos para estabilizar significados, esses lugares também guardam potência e abertura para contestações. Desse modo, da mesma maneira que eventos e rituais recentes se elaboram em Ouro Preto para destacar uma dimensão daquela cidade ligada a certos discursos de identidade, como faz a Semana da Inconfidência, outros eventos disputam as representações, os imaginários e as emocionalidades que os objetos nela existentes podem despertar. Esse é o caso dos festejos de coroação de reis negros realizados por congadeiros e congadeiras do Alto da Cruz, um coletivo de pessoas negras que a partir dos seus rituais festivos recupera objetos e materialidades da cidade ressaltando identidades que foram negligenciadas ou estereotipadas. Ao criar uma densidade de eventos em relação a algumas das igrejas de irmandades negras na cidade, destacando em suas performances rituais a biografia de santos negros, como São Benedito e Santa Efigênia, e de figuras que criaram iniciativas de resistência à escravização, caso de Chico Rei, os coletivos negros, a partir de festas de exaltação da negritude, recuperam e reelaboram sentidos para tornar mais densas e complexas as camadas de significados que foram constituindo Ouro Preto como um lugar simbólico. Assim, o Reinado do Alto da Cruz, além de ser um festejo de cunho religioso, é também uma festa negra. Ao mesmo tempo em que é uma possibilidade de louvação aos santos e 
de reverência aos ancestrais a partir de uma experiência do sagrado, ele recupera e dá continuidade a uma memória da negritude, de modo a tornar conhecida e durável a trajetória de determinado povo.

Considerando o problema de pesquisa comunicado neste artigo é possível afirmar, portanto, que a partir da vivência do sagrado e da sustentação de uma memória dos povos negros, a festa do Reinado do Alto da Cruz realiza um itinerário simbólico que se comunica com um lugar de elevado poder discursivo no que se refere às identidades. Trata-se da relação com uma paisagem patrimonial que tanto para os moradores de Ouro Preto quanto para os outros brasileiros se constitui como um emblema nacional. E dado o peso que ela possui nas políticas de identidades e de significados, o Congado, ao estabelecer um determinado discurso de negritude que recupera memórias e referências, acaba por tensionar com as imagens que essa paisagem veicula.

Desse modo, embora o Reinado reconheça paisagens que Ihes são próprias, com a irrupção de cores e sons nos dias festivos, ele também realiza uma articulação com a paisagem patrimonial ouro-pretana, assim como o fazem tantas outras festas que têm seu acontecimento naquela cidade. Nessa medida, é também com a paisagem patrimonial valorizada pelas instituições da memória que os congadeiros pretendem negociar ao realizarem seus deslocamentos rituais pelo espaço, porque sabem que é com essa ressignificação que conseguirão transformar as representações de suas identidades para o imaginário coletivo a partir de uma referência positiva. Assim, a pesquisa permitiu interpretar que as representações, imaginários e emocionalidades de negritude elaborados pelos órgãos oficiais e pelos grupos de Congado são interdependentes. Ainda que possuam algumas distâncias, uma vez que as coletividades que as produzem de fato ocupam posicionamentos distintos nas geometrias de poder, essas diferentes forças se tocam a partir das interseções existentes entre os grupos sociais que em conjunto produzem a paisagem patrimonial de Ouro Preto.

\section{REFERÊNCIAS}

ABREU, R. Colecionando museus como ruínas: percursos e experiências de memória no contexto de ações patrimoniais. Ilha, Florianópolis, v. 14, n.1, p. 17-35, jan./jun., 2012. Disponível em: https://bityli.com/DtNV4 Acesso em: 17 ago. 2017.

AGUIAR, L. B. Cidade morta, cidade documento, cidade turística: a construção de memórias sobre Ouro Preto. In: CASTRO, C.; MAGALHÃES, A.; SALGUEIRO, V. (Orgs.). História do Turismo no Brasil. Rio de Janeiro: EdFGV, 2013. p. 180-193. 
AGUIAR, L. B. Turismo e preservação nos sítios urbanos brasileiros: o caso de Ouro Preto. 2006. 323 f. Tese (Doutorado em História, UFF). Universidade Federal Fluminense, 2006.

AMARAL, R. C. M. P. Festa à brasileira: sentidos do festejar no país que 'não é sério'. 354 f. Tese (Doutorado em Antropologia). FFLCH/Universidade de São Paulo, 1998.

ANDERSON, B. R. Comunidades imaginadas: reflexões sobre a origem e a difusão do nacionalismo. São Paulo: Companhia das Letras, 2008[1983].

CHUVA, M. Fundando a nação: a representação de um Brasil barroco, moderno e civilizado. Topoi, Rio de Janeiro, v. 4, p. 313-333, 2003. Disponível em: https://bityli.com/7|3yx Acesso em: 10 abr. 2017.

CORRÊA, R. L. Espaço e Simbolismo. In: CASTRO, I. E.; GOMES, P. C. C; CORRÊA, R. L. (orgs.). Olhares geográficos: modos de ver e viver o espaço. Rio de Janeiro: Bertrand Brasil, 2012. p. 133-153.

COSGROVE, D.; DANIELS, S. Introduction: iconography and landscape. In: The Iconography of landscape: essays on the symbolic representation, design and use of past enviroment. Cambridge: Cambridge University Press, 1989. p. 1-10.

COSTA, E. B.; SCARLATO, F. C. As fases de (re)produção do patrimônio cultural brasileiro: interpretação e valoração da paisagem urbana da gênese colonial à mercantilização das cidades históricas no Brasil. OLAM - Ciência e Tecnologia, v. 9, n. 1, p. 07-47, 2009. Disponível em: https://bityli.com/VEF50 Acesso em: 02 maio 2021.

DAMATTA, R. Carnavais, Malandros e Heróis: para uma sociologia do dilema brasileiro. 2 ed. Rio de Janeiro: Zahar Editores, 1980.

DANIELS, S.; COSGROVE, D. Spectacle and text. Landscape metaphors in cultural geography. In: DUNCAN, J.; LEY, D. (orgs.) Place/culture/representation. London: Routledge, 1993. p. 57-77.

DELL'AIRA, A. Johann Moritz Rugendas e a Lenda de Chico Rei. Desígnio: revista de história da arquitetura e do urbanismo, São Paulo, n. 9-10, p. 137-147, set. 2009.

DEUS, J. A. S.; TORRES, M. A.; ALMEIDA, M. G.; VARGAS, M. A. M. Territorialidades de festas populares: espaço-tempo cognitivo, conectivo e conflitivo. Revista da ANPEGE, $n$. 18, p. 353-368, 2016. Disponível em: https://bityli.com/VEF50 Acesso em: 02 nov. 2017.

DIAS, P. A 'outra' festa negra. In: JANCSÓ, I.; KANTOR, I. Festa: cultura \& sociabilidade na América portuguesa. São Paulo: Hucitec/Edusp/FAPESP/ Imprensa Oficial do Estado, 2001. p. 859-888.

DUNCAN, J. The City as Text: The Politics of Landscape Interpretation in the Kandyan Kingdom. Cambridge: Cambridge University Press, 1990.

DURKHEIM, E. As formas elementares da vida religiosa: o sistema totêmico na Austrália. São Paulo: Martins Fontes, 1989[1912]. 
DUVIGNAUD, J. Festas e Civilizações. Fortaleza: Edições UFCE; Rio de Janeiro: Tempo Brasileiro, 1983[1974].

FURTADO, J. F. Desfilar: a procissão barroca. Revista Brasileira de História, São Paulo, v. 17, n.33, p. 251-279, 1997.

GEERTZ, C. A interpretação das culturas. Rio de Janeiro: LTC, 1989.

GONÇALVES, J. R. S. Autenticidade, Memória e Ideologia Nacionais: o problema dos patrimônios culturais. Estudos Históricos, Rio de Janeiro, v.1, n. 2, p. 264-275, 1988.

KOPTCKE, L. S. Bárbaros, escravos e civilizados: o público dos museus no Brasil. Revista do Patrimônio Histórico e Artístico Nacional, Brasília, n. 31, p. 37-57, 2005.

LIMA FILHO, M. F. Espelhos Patrimoniais em Ouro Preto: museus e passado afrobrasileiro. Tomo, Aracaju, n. 16, p. 197-220, 2010. Disponível em: https://bityli.com/ZugaL Acesso em: 07 maio 2021.

MAIA, C. E. S. Paisagens festivas e interações mítico-ritualísticas em práticas tradicionais do catolicismo popular. Espaço e Cultura, Rio de Janeiro, n. 30, p. 19-35, jul./dez. 2011. Disponível em: https://bityli.com/8yZFi Acesso em: 14 set. 2016.

MAIA, C. E. S. Ritual e emoção nas interações espaciais - repensando o espaço sagrado nas festas populares de romarias e folguedos (Notas introdutórias). In: ROSENDAHL, Z. (org.). Trilhas do sagrado. Rio de Janeiro: EdUERJ, 2010. p. 87-111.

MAIA, C. E. S. Enlaces Geográficos de um Mundo Festivo - Pirenópolis: a tradição cavalheiresca e sua rede organizacional. 300 f. Tese (Doutorado em Geografia). Rio de Janeiro, PPGG/UFRJ, 2002.

MANDOKI, K. Sites of symbolic density: a relativistic approach to experienced space. In: LIGHT, A.; SMITH, J. M. Philosophies of Place. Lanham: Rowman \&Littlefield, 1998. p. 73-95.

MARTINS, L. M. Afrografias da Memória: o Reinado de Nossa Senhora do Rosário no Jatobá. São Paulo: Perspectiva; Belo Horizonte: Mazza Edições, 1997.

MASSEY, D. Pelo espaço: uma nova política da espacialidade. Rio de Janeiro: Bertrand Brasil, 2008.

MAYOR, S. O Carnaval de Ouro Preto: mercado e tradição (1980-2011). Dia-logos, Rio de Janeiro, v. 7, p. 183-196, 2013. Disponível em: https://bityli.com/iCkWY Acesso em: 10 jan. 2017.

MOTTA, L. A SPHAN em Ouro Preto - uma história de conceitos e critérios. Revista do Patrimônio Histórico e Artístico Nacional, Rio de Janeiro, n. 22, p. 108-122, 1987.

PEREIRA, E. S. O santo, a face e o outro: quando Cristo e Tiradentes se encontram em Ouro Preto. Etnográfica, Lisboa, v. 20, p. 363-386, 2016. Disponível em: https://bityli.com/CjqgR Acesso em: 10 maio 2021. 
PEREZ, L. F. Dionísio nos trópicos: festa religiosa e barroquização do mundo - por uma antropologia das efervescências coletivas. In: PASSOS, M. (Org.). A festa na vida: significado e imagens. Petrópolis: Vozes, 2002. p. 15-58.

PEREZ, L. F. Festas e viajantes nas Minas oitocentistas, segunda aproximação. Revista de Antropologia, São Paulo, v. 52, p. 289-338, 2009. Disponível em: https://bityli.com/JkNaT Acesso em: 10 jun. 2021.

ROCHA, D. Acontecimento e memória (2): encontro de gêneros discursivos que (re)contam a história de um Brasil-ainda-colônia. Revista da ANPOLL, v. 37, p. 180-198, 2014. Disponível em: https://bityli.com/ZUV8d Acesso em: 02 fev. 2017.

ROSA, M. C. Lazer e juventude: festa e turismo em Ouro Preto. Licere, Belo Horizonte, v. 3, n.1, p. 134-146, 2000. Disponível em: https://bityli.com/chNgi Acesso em: 15 out 2017.

ROSENDAHL, Z. Geografia da Religião: uma proposição temática. Geousp, São Paulo, n.11, p. 9-19, 2002. Disponível em: https://bityli.com/YIRNF Acesso em: 22 jul. 2016.

SANCHIS, P. A caminhada ritual. Religião e Sociedade, Rio de Janeiro, n. 9, p. 16-26, jun. 1983.

SANTOS, M. S. Canibalismo da memória: o negro nos museus brasileiros. Revista do Patrimônio Histórico e Artístico Nacional, Brasília, n. 31, p. 37-57, 2005.

SHURMER-SMITH, P. Postcolonial geographies. In: (ed.) Doing Cultural Geography. London: SAGE, 2008. p. 67-77.

SILVA, R. A. Chico Rei Congo do Brasil. In: SILVA, V. G. (org). Imaginário, Cotidiano e Poder - Memória Afro-Brasileira. v. 3. São Paulo: Selo Negro, 2007. p. 43-86.

SOUSA, P. P. A. Que geografias lembrar? Paisagens, lugares e itinerários simbólicos da negritude em Ouro Preto-MG. 363 f. Tese (Doutorado em Geografia) IGEO, UFRJ, Rio de Janeiro, 2018. Disponível em: http://objdig.ufri.br/16/teses/881324.pdf Acesso em: 10 jun. 2021.

SOUSA, P. P. A.. Os lugares da festa: narrativas de espaço, tempo e etnicidade no Congado mineiro. Geografias, Belo Horizonte, v. 13, n. 2, p. 39-56, 2016. Disponível em: https://bityli.com/DTOzy Acesso em: 10 jun. 2021.

SOUZA, M. M. Reis negros no Brasil escravista: história da festa de coroação de Rei Congo. Belo Horizonte: EdUFMG, 2002.

VIANA, F. H. A paisagem sonora de Vila Rica e a música barroca das Minas Gerais (1711-1822). Belo Horizonte: cl Arte, 2012. 